\title{
The Experiences of Children Growing up in Lesbian-Headed Families in South Africa
}

\author{
Carien Lubbe
}

\begin{abstract}
In the fairly short historical period since the adoption of a new constitution, there appears to be an increasing openness and visibility of same-gender relationships and families in South Africa. For example, gay and lesbian couples started to adopt children in openly gay relationships during the decade of the 1990s, previously married parents live more openly with their same-gender partners, and lesbian couples are creating their own families due to changed legislation regarding donor insemination. This article highlights findings from a study that explored the experiences of children growing up in lesbian-headed families. Utilizing a narrative inquiry, I captured the reported experiences of the children from their perspectives as they interacted with people in their lives. I also inquired into the ways in which they negotiate the heteronormativity of society. The findings reveal an interconnectedness between key aspects of disclosure, awareness, OKness, openness, and openmindedness. Capturing these experiences of children provides us with insight into how children themselves experience their life worlds and expand our understanding of what it means for children growing up with lesbian parents.
\end{abstract}

KEYWORDS. Lesbian-headed families, same-gender families, disclosure, OKness, awareness, openness, children of gay parents 
Traditional views regarding families are being challenged by the increasing prevalence of nonconventional family arrangements. At the outset of the 21st century, people are choosing to live their lives and rear their children in associations that only 50 years ago would not have been regarded as families. Societal factors such as working mothers, adoption, divorce, and HIV/AIDS have all played a part in influencing the ways in which nontraditional family forms have developed. One such nontraditional family form that has challenged society's traditional notion of what a family means is the same-gender family (Dunne, 2000). For the purposes of this article, I focus on lesbian-headed families.

My personal position is that lesbian-headed families present new challenges to the privatized nuclear family. Lesbian-headed families raise suspicions and engender skepticism in some quarters because any departure from the traditional family system and structure raises uncomfortable questions such as: "What is a parent?"; "What is a family?"; "What is a father and what is a mother?" Lesbian-headed families challenge dominant notions not only of gender but also of sexuality.

It might be asserted that the married, two-parent, heterosexual couple has been the norm against which all other kinds of couples are measured, evaluated, and judged. These generally assumed and usually unchallenged belief systems create a dominant narrative of what a family is or should be-a narrative that maintains that heterosexuality is the preferred and sanctioned mode of intimate relationships and family life. This dominant narrative creates a perception that the lesbian-headed family is different and something other or alternative.

Because most families convey strong heterosexual messages, they provide many opportunities for their children to receive positive reinforcement, approval, and validation for their heterosexual orientation. This is also true of South Africa, which is traditionally a strongly family-based society with a culture in which the traditional family is prominent, powerful, visually present, and valued. Most parents encourage the dating of opposite-gender individuals, marriage, and eventually children—especially as adolescence and sexual maturity approach.

Although heterosexuality and its accompanying destiny in straight nuclear families are still assumed as a desirable norm for ordinary people, this singular view cannot be taken for granted anymore in the realm of academic scholarship. Queer scholars argue that gay individuals and families are moving beyond the closet and that we are entering a post-gay era. Heterosexist nuclear family concepts and language also do not describe the reality of family connections in many other minority groups (Clunis 
\& Green, 2000). Postmodern living arrangements are diverse, fluid, and unresolved; they are constantly chosen and re-chosen, and hetero-relations are no longer as hegemonic as they once were.

My interest for investigating lesbian-headed families is to explore what happens to children of lesbian parents when they move from their homes into the world and how they negotiate the possible difficulties inherent in inviting the world (in the form of close friends, classmates, peers, other significant adults) into their family homes. Because of the current topicality and visibility of lesbian parents in South Africa (mainly as a result of intense media interest in some high-profile Supreme Court cases in recent years) and because lesbian-headed families are a new concept for most people in society (both in terms of family structure and the homosexual sexual orientation/preference of the parents), how the children involved would perceive their families and construct the acceptability of their families in the community and society is a matter of intense interest to me. I wondered whether the children would see their families as (in essence) no different from other families or whether they would perceive their families as being different - and, if so, how they felt about it. As my research gained momentum, I came to realize that there are no clear-cut answers to any of these questions. Little is known about the ways in which children in lesbianheaded families function within the predominantly heterosexual society, what makes such functioning possible, and what makes such functioning easy or difficult to manage.

In this article, I present findings from research exploring the experiences of children growing up in lesbian-headed families in order to inform our current understanding of how children experience the social construction of lesbian-headed families. I am adding my voice to the growing literature on lesbian-headed families, specifically from the viewpoint of children growing up in lesbian-headed families. Even though research into lesbian-headed families has increased over the past few years, a limited number of qualitative studies have investigated in-depth the experiences of children of lesbian parents. The children reported their experiences to me in terms of their interaction with their close friends, classmates, peers, other significant adults (such as their friends' parents), and other adults somewhat more peripheral to their lives (such as school teachers or ministers of religion). These interactions culminate into coming out/disclosure experiences, as they negotiated their worlds with the outside world. I therefore unpack disclosure in terms of interrelated concepts that emerged from an analysis of their experiences. Among these interrelated concepts of awareness, OKness, openness, open-mindedness, 
and support, disclosure emerged as the dominant concept by positioning itself as one of the main experiences of children growing up in a lesbian-headed family, especially when such lesbian-headed families are viewed against a backdrop of a heteronormative discourse. Even so, the centrality of disclosure does not negate the importance of the other concepts because all these concepts are interconnected both in theory and in practice.

\section{RESEARCH DESIGN}

I have used a narrative research design to answer the research questions: (a) What are the experiences of children growing up in lesbian-headed families? and (b) How do they negotiate the heteronormativity of society? I view a lesbian-headed family as one where both parents are of the same female gender (biological sex) and who are involved in a romantic relationship.

I chose narrative inquiry because it attempts to understand and represent experiences through the stories that individuals live and tell (Creswell, 2002). The narrative inquirer tells and retells, lives and relives, presents and re-presents the stories that make up people's lives, individually and socially, in order to answer questions of meaning, experience, and social significance (Clandinin \& Connelly, 2000). I aimed to understand the experiences of children growing up in families with lesbian parents: how they think and feel about their lives in relation to the heteronormative image of family life that society constantly projects. I have accessed and explored the reported experiences of the children of lesbian parents. These reported experiences include first-person accounts, interpretations, memories, thoughts, ideas, opinions, understandings, emotions, feelings, perceptions, behavior, practices, actions, activities, conversations, interactions, secrets, inner-self monologues, and so on (Mason, 2002, p. 53).

\section{Sample}

Eight children (four boys and four girls) from five lesbian-headed families became my research partners (participants), and they were identified by using the technique of snowball sampling based on the criteria of accessibility. This meant that I could be assured of predetermined levels of reliability and convenience when it came to coordinating times and 
places for meetings with my research families. This was necessary for maintaining the momentum of the research relationship. In practice, it meant that the families concerned all lived within a reasonable distance from where I worked and/or lived and that they were able and willing to make time available for regular meetings. The ages of the children ranged from 9 to 19 years, four being in primary school, three in secondary school, and one had just finished her formal schooling years. Two of the children belong to the racial group referred to as Coloreds, and the other six would be regarded as belonging to the racial group identifiable as White. Although I used no formal instrument to measure their socioeconomic status, one family belonged to a low-income group, another belonged to a high-income group, and the remaining three families lived in neighborhoods that one would associate with middle-income families. I preferred to work with parents of female gender; therefore, all of the participants' mothers were lesbian. While I could have based my research on male couples living as same-gender parents, I intentionally chose female couples for the purpose of this inquiry. The basis for this decision was mainly personal preference, which I can ascribe to my own gender being a female and my preference for a partner of the same gender.

The decisions I made were also influenced by the increasing openness and visibility of same-gender relationships and families in South Africa in the fairly short historical period prior to and contemporary with my research. Gay couples started to adopt children in openly gay relationships in the decade of the 1990s (Jordaan, 1998; Singh, 1995), while the Human Tissue Act that made donor insemination for lesbians legally possible was amended in 2000 (Underhill, 2003). Before this amendment, donor insemination was not legally possible for any unmarried woman in South Africa. Under these circumstances, I made the assumption that lesbian-headed families who were open and out about their situation were a relatively new phenomenon. I therefore focused mainly on lesbian couples that included previously married mothers who had older children from heterosexual marriages or lesbian couples who had adopted older children because such families would be in possession of the kind of information that I was seeking for my research.

\section{Procedure for Data Collection}

I conducted weekly in-depth interviews with each child and his parents (separately and combined in the case of some families) over a 
period of 3 to 4 months, utilizing supportive data creation methods such as collages, time lines, family stories, and artifacts. I made use of unstructured interviews because this type of interview offers the participant an opportunity to tell her story with minimal interruption by the researcher. Unstructured interviews are most appropriately used in studies where the researcher seeks to learn primarily from participants what matters (Morse \& Richards, 2002). The role of the researcher is to listen and let the participant tell her story. The researcher can ask questions about whatever is not clear, preferably during a second interview. Unplanned, unanticipated questions may be used as well as probes for clarification.

In particular, I started off with each interview informing the children about the purpose of my study, that I wanted to know what it is like to be living in a lesbian-headed household using appropriate vocabulary as the parents indicated in my initial contact session. Some families used the phrases two moms or living with another woman and some used the words lesbian partners. Initially, I began by asking a general introductory question such as: "Tell me about your family" or "What is it like to have two mothers?" Later on I used the style of informal conversations characterized by general conversation such as talking about the day at school, which provided me with opportunities to probe more gently into specific matters; e.g., their friendships, whether they have sleepovers, and so forth, which usually evoked details about their negotiation between their intimate private lives and the world outside their families.

What I came to realize was that the relationships that I was building with the children and families made an enormous impact on me and decisively affected the research process. Factors such as the extent to which I got along with them, the extent to which the child trusted or began to trust me, whether or not I missed cues, and the extent to which the child would speak by becoming silent, talkative, or voluble. I really had to work to acquire the skill of not-knowing in order to truly understand the depth of what is meant and implied by socially constructed meanings. To understand that, I constructed knowledge through my questions and the manner in which I listened to answers, how I reacted to these, and how the children reacted to my questions or comments.

The argument may be put forth as to how much the participants were prepared to reveal about their inner experiences and daily lives. Working from a social constructionist and poststructuralist paradigm, I suggest that no authoritative discourse to which all other knowledge must be subordinated exists, and that because all perceptions are provisional, all texts 
are therefore provisional. In my view, the knowledge and meaning that we derive from what we engage in is more like construction than finding or discovering (Alvesson \& Sköldberg, 2000; Schwandt, 2000). Furthermore, my epistemological view is that knowledge (in the sense of an understanding of one's reality) is relative, plural, and subjective and that the researcher and the research partners cocreate this understanding. This does not imply that the researcher is the one who knows. I see quite clearly that the individual who has permitted me the privilege of conducting research into her or his private reality is the knower and (quite obviously) the expert on her life. It is possible to obtain knowledge of another person's inner reality by carefully and systematically examining the views, meanings, experiences, accounts, actions, and events that occur in that person's life. Such understandings are cocreated by both the researcher and the participant. Both their voices will be discernible in the conclusions because there is no single interpretive truth that is entirely valid (Denzin \& Lincoln, 2000). As I said above, the truth is always subjective and personal. I have therefore adopted an approach that enables me to produce (in cooperation with my research partners, supervisor, and critical readers) reconstructed understandings of the experiences of children who are growing up in lesbian-headed families.

\section{Data Analysis}

The data analysis process is an iterative process that continually moves backwards and forwards between the research text, the data creation, data analysis, and interpretation. However, during the formal analysis phase, I began with the idea of utilizing the categorical-content approach of Lieblich, Tuval-Mashiach, and Zilber (1998), which basically entailed a thematic analysis of the content. As I read through the field texts and searched for tentative themes, I could code each child's separate story with relative ease but it seemed futile to me to perform a cross-case analysis in which I would look for themes across cases (Patton, 1990). I found that the necessity of having to downplay the specific case dynamics of each individual case bothered me because the uniqueness and individuality of each story got lost in the process. Although I could see similarities between cases and strong similarities across two or three stories, there were also distinct differences or nuances that I needed to include. I wanted to capture the uniqueness of the experiences of the children growing up in lesbian-headed families and a search for common cross-sectional themes did not provide me with this. I realized that the 
imposition of a consistent coding scheme onto in-depth interviews might even render my research invalid (Morse \& Richards, 2002) because it would not facilitate the answering of my research question. Clandinin and Connelly's (2000) statement, "When participants are known intimately as people, not merely as categorical representatives, categories fragment" (p. 141) made me realize that I had to use a different approach for my analysis.

I once more revisited the literature and found an answer in Jennifer Mason's words. Mason (2002) made me appreciate that I was searching for the "particular in a context, rather than the common or consistent and for the holistic rather than the cross-sectional" (p. 165, emphasis added). Explanatory or analytical logic supported by a holistic organization of data can illuminate the experiences of children growing up in lesbian-headed families and can provide an explanation of the ways in which the children of lesbian parents engage with their world. I decided to go back to my field texts and immerse myself in my data.

In order to organize my data holistically, I reread the raw transcripts and field notes on the collages and time lines without highlighting themes. I simply read through the material several times to form an overall impression of what each specific child's story was about. My earnest desire was to understand the intricately interwoven parts of each unique story. It was from this emergent overall impression that general patterns in each individual story began to emerge in my mind. I then used colored markers and colored pens and started to work through the field texts again. I then identified narrative threads, tensions, and patterns within the field texts of each story. I grouped, labeled, organized, and sorted the data that were necessary to understand each individual child and then proceeded to write a narrative for each child.

In this way, I inductively analyzed the created data to obtain a rich and descriptive account of those subjective experiences that my research partners were willing to share with me. These narratives were written to present and represent a descriptive as well as an explanatory account of the experiences of children with lesbian parents. These narratives capture the subjective feel of their particular experiences and enhance the understanding of the social world in which these children live (Willig, 2001). Working with narratives enabled me to shift the focus of my inquiry and look with great intensity at whatever was small, minute, specific, and individual. This approach allowed me to illuminate the uniqueness, the specificity, and the individuality of each child in this study while at the same time situating their experiences within their social context. 
Having written the narratives, I proceeded with the interpretative phase. I once again utilized Mason's (2002) holistic analysis as an interpretive tool in which I now confronted the data with analytical questions of meaning and significance. The following question was asked in order to frame and focus the experiences of children in lesbian-headed families: "What do I know now that I did not know before about the experiences of children growing up in lesbian-headed families?"

Interpretations generated while reading and analyzing the narratives reminded me of grounded theory analysis, which generates categories that emerge from the data. I started by viewing the experiences of children growing up in lesbian-headed families from their perspectives since the experiences are grounded in the children's words. The narratives are the mold into which I have poured their experiences. Interpretations would then emerge from these narratives.

And so I stumbled upon the idea of calling this process a grounded narrative. The narrative is grounded in the data, and the interpretations emerged from reading and analyzing the narratives against a backdrop of the field texts as background data. Interrelated themes emerged from this analysis: (a) disclosure; (b) open-mindedness and openness; (c) awareness; and (d) OKness. I took each story and selected specific supporting evidence (quotations) in order to test this developing explanation (Mason, 2002). For example, one theme that emerged with prominence was that of a being $\mathrm{OK}$ and OKness with having two mothers as parents. A continuum with different degrees of OKness emerged, and this tentatively suggested that some children were experiencing a greater degree of OKness than others. I reflected on this theme and questioned my own role in seeing this theme emerging. I questioned my influence on the interpretive process. I decided to search for the opposite, for examples of not-OKness among the children. When I did this, the theme of protection, of a need to protect themselves from the heteronormativity of society, emerged strongly. I then realized that while experiences of OKness/not-OKness among the children did indeed exist on a continuum, the data from my study revealed stronger indications of OKness among the children. In addition, the theme of protection was negated when the data revealed another significant type or kind of OKness, namely the OKness to disclose/not to disclose, which did not necessarily arise out of any need for protection. A similar process was followed in terms of the interrelated themes of awareness, open-mindedness, and openness, building toward this conceptualization of the experiences of children growing up in lesbian-headed families, which I will now unpack. 


\section{FINDINGS AND DISCUSSION}

As I worked through the children's stories and immersed myself in their reported experiences, I realized that there exists a tension between the nothingness of growing up in a lesbian-headed family and the need that the children have to negotiate their position vis-à-vis the heteronormative discourse that still prevails in society and cultures. It becomes a challenge for children growing up in lesbian-headed families to legitimate their personal stories in such a way that they reach some kind of accommodation with the structural and social stories that function in society (Jenness \& Richman, 2002; Kenyon \& Randall, 1997).

\section{Awareness and Disclosure}

It is obvious from their stories that the heteronormative discourse becomes visible through the thoughts and actions of their peers, close friends, other parents and teachers, and through the all-pervasiveness of mainstream (as opposed to countercultural or alternative) media. The children without exception are aware that people in general hold different points of view, perceptions, and feelings about lesbian parents and lesbian-headed families. The following examples from the children indicate their awareness and sensitivity:

Luanne: We just don't want to advertise that my parents are gay. We all just want to get on with our everyday lives, and we hardly ever bring up questions like this when we are alone. ... Not everyone is open and $\mathrm{OK}$ with this kind of situation.

Luanne's observation that "not everyone is open and OK" reveals that she is quite aware of prejudice and discrimination and has therefore resolved to protect herself and those she cares for against the possibility of being ridiculed or worse. Another explanation might be that because different people have different moral standards, discretion acts an effective strategy to protect effective relationships and promote peace and harmony in any given situation.

Kim: Obviously, he and his friends all know. But my friend, Jane, for example. She doesn't know, and I don't discuss it with her. Different people have different attitudes, and you can never be sure. 
Kim's disclosure depends on the other person's apparent openness and open-mindedness. Her statement that "different people have different attitudes" shows her awareness of different viewpoints in society and one can maybe derive a sense of insecurity and apprehension in her words "you can never be sure."

Kashni is aware of the feelings and reactions of others and possesses a finely developed sense of whether or not other people may be feeling uneasy or uncomfortable:

Kashni: I can feel it sometimes when I talk about my parents. Or, if I invite them to my house and then sense that my invitation has made them feel uncomfortable. Or sometimes I invite them and I can see that they would prefer not to come. ... If a friend of yours is, like, very open and tolerant ... then you can speak out without any problems at all. Or if you can see where a person is coming from, and they are not hostile, you can talk to them openly.

An analysis of her ability to sense the perceptions of others of her family situation reveals the complexity of the disclosure process and how difficult it sometimes is to decide who to tell and when to raise the topic in conversation. Sometimes she gets a feeling (intuition). At other times, she reads other people's nonverbal cues. Sometimes she directly notices their uneasiness and this confirms her own intuition that all is not well. Kashni seems able to perceive very quickly how open a person may be, and she displays a remarkable ability to reflect on what is happening in any given situation and to assess alternative explanations for someone else's behavioral or nonverbal cues.

I conclude, then, that the children of lesbian parents in this sample experience a whole spectrum of reactions that range between rejection and prejudice (at one end of a continuum) to tolerance, acceptance, and a belief that lesbian-headed families are just another variation in family structure (at the other end of the continuum). Because their own experience has made these children aware that people's reactions to their lesbian-headed families vary from enthusiastic acceptance or indifference to intense hostility, they have all (in varying degrees) become conscious about how much they are prepared to reveal about their lesbian-headed families — and sensitive about how this information might be received by others. This awareness leads them either not to disclose or to disclose the fact that they have lesbian parents. 


\section{OKness and Disclosure}

Apart from the link between awareness and disclosure, the children also exhibited different levels of OKness with growing up in a lesbianheaded family. While someone might wonder at my use of the phrases $O K$, being $O K$, and OKness and their variant forms because of their informality or designation as colloquialisms in most dictionaries, I use these terms in the text in a deliberate and conscious way that imbues these terms with more depth and meanings that go beyond their everyday colloquial use.

In this text, they imply the capacity of the children to be in emotional, cognitive, and even spiritual congruence with the fact that they have two lesbian women (mothers) as parents. This would then also imply that they are in harmony with this fact of their lives, that they acknowledge it, and that they do not deny it. Being refers to be, to exist, and, thus, a state of being or a state of existing. Being OK indicates that there exists in the children a generalized feeling and frame of mind that in turn indicates an inner awareness of, contentment with, and acceptance of the fact that they have two lesbian mothers. These terms also indicate the nuances of being satisfied with, content with, at ease with, at peace with, and all right with having two mothers, which, taken together, might also indicate acceptance of having two lesbian mothers.

Acceptance in psychological terms is a complex and deep process that is usually achieved after a prolonged contemplation of different factors (Kübler-Ross, 1986). The terms acceptability, adaptation, and adjustment also imply the existence of external processes that are associated with social approval and social acceptability. While these processes are important and certainly play a role in the any conviction of OKness, they do not capture the particular meaning of what being OK implies (as it is used in this text). After much consideration of possible alternatives, I could find no terms more apt or suitable for conveying the acceptance of their lesbian parents on the part of the children than what is conveyed in the terms being $\mathrm{OK}$ and OKness. To me these words signal an authentic and fundamental awareness, feeling, and belief that the children I have interviewed have an unfolding experience and an intuitive knowing that their lesbian mothers are OK in every way.

In examining the OKness of children growing up in a lesbian-headed family, I cannot separate it from the interactions they have with others. In the way in which they talk to their friends, their classmates, or other significant people, their OKness is displayed. Being OK becomes visible 
in how they share the phenomenon of having two mothers, linking being OK with disclosure or coming out.

Furthermore, from the research conducted, I propose that there are different kinds of OKness that children growing up in a lesbian-headed family experience. One kind of OKness is the different levels of being OK with having lesbian parents. These different levels may be placed on a scale that ranges between being not $\mathrm{OK}$ to being $\mathrm{OK}$. The other kind of OKness ranges between being $\mathrm{OK}$ to disclose this information and being $\mathrm{OK}$ to withhold it.

However, none of the children of this sample takes up an absolute position on this issue. My research shows that a continuum exists between disclosure and nondisclosure, and that (as one might expect) no child consistently takes up a consistent position on the continuum but will react in various ways to different circumstances. Thus, while children may disclose quite openly on some occasions, they will choose at other times to disclose in a minimal (meaning that only small detail will be shared; for example, only answering questions in a yes or no manner) or masked (for example, framing the second mother as a friend or aunt) way. The extent and method of their disclosures are designed to deal with the circumstances with which they are confronted.

Being OK highlights the contrast with those who do not feel OK with the reality of lesbian parenthood either because they know no lesbian-headed families or because of other reasons such as their own moral or religious values. Their sense of being OK may also be shaken by the hostility or ignorance of other people's reactions. The sign that probably indicates most notably that they are not $\mathrm{OK}$ is the fear they express should someone find out that they have two mothers. I could therefore deduce their being $\mathrm{OK} /$ being not OK from the way in which they disclose (or do not disclose). The interrelated link between OKness and disclosure emerges continually and warrants further exploration.

\section{Being OK to Disclose}

Let me explore how and when children from lesbian-headed families in this sample disclosed from a position of being OK. Most of the children that I interviewed realized that they cannot hide the fact that they have lesbian parents (two mothers) from the world. They therefore resorted to being as straightforward as prudence, circumstances, and common sense allow, and they utilized truth, honesty, and openness to good effect when their significant relationships are at stake. They felt that the other (significant) 
people who crossed their life paths should know about their situation and that they should feel open and comfortable with it:

Carl: Why should I lie to them? If someone doesn't want to accept me because my parents are gay, then that's OK. I've got lots of friends. I don't need people like that.

The children growing up in lesbian-headed families that I interviewed are all fully aware that by disclosing they risk losing someone's acceptance and the possibility of an intimate relationship. But if a more authentic relationship is to develop, they know that full disclosure and openness are necessary. Let me explore this by using Kashni as an example:

But then I have other friends, certain friends I'm not really close to. I mean, I am friendly with them, but I don't talk to them the whole day and they don't come to my home. Which doesn't bother me. ... If they hear about my parents it's fine. They're usually fine with it as well. But in the case of my best friends, those friends I talk to every day, then I must tell them.

She elaborates on this "must tell" by saying:

... otherwise I just feel uncomfortable. If they come to my home and they don't understand the situation before the time, then it could be very uncomfortable for them, especially if they have come for a sleepover.

This remark indicates that disclosing for Kashni is a prerequisite for being OK. Kashni's sensitivity toward others, and especially toward her friends, enables her to help and guide them by giving them information beforehand so that they will not be surprised or overwhelmed. I also discern a caring and protective attitude in Kashni in wanting to disclose to her friends before they hear about her lesbian parents and in caring about how they will handle any (possible) unforeseen circumstances. She therefore assumes the role of an active agent in helping her friends to understand and adjust. This makes her an active agent in negotiating the construction of her situation with the outside world. Kashni also uses a distinctively straightforward manner when she discloses: "I just say to them upfront: 'Listen, I have two mothers, OK?"” 
Disclosure then serves both to enhance and support authentic relationships and to safeguard friendships. The children thus used indications of uncertainty and/or discomfort as signals that warn them that the time has come to intervene and disclose. Tom serves as an excellent example in displaying awareness and ability to anticipate any apprehension, anxiety, or uneasiness in others:

I would only mention it if someone were unfamiliar with the setup in my house. When I invite my friends to my house, I want them to feel comfortable. So then, if they don't know about my two mothers, I tell them. It doesn't help if I keep secrets from them and then they have to wonder what is going on. But then they understand. I put them in the picture. My friends and I are all very straightforward with each other. It's our big thing....

No. I would tell them if I see that they are uncomfortable. Sometimes, a new friend arrives. They see my two moms. I don't know what they are thinking, but it feels funny. It is as though they suspect something. They're like, "I'm not suppose to be here, it's not the right place to be." [He smiles, but continues.] When they look a bit suspicious, I just tell them quietly what the setup is.

Carien (Researcher): So you might see that they are feeling awkward?

Tom: Yes. And then I just explain what is going on. As soon I detect that they are feeling uncomfortable and not acting normal, then I tell them. I ask them what is wrong and when they withdraw a little, I ask them gently if they have a problem, if it's OK for them, and if I can explain how it works. Basically, I want them to feel OK. So if they feel unable to explain how we live to their parents, I tell them that my mom could contact their parents and tell them about our household - if that's what they would prefer.

Let me unpack this example in the following way. Tom displays a sensitivity in observing his friends and picking up on their nonverbal language, especially their facial expressions and general demeanor. He shows foresight and sensitivity in anticipating what they might be thinking. This enables him to take appropriate action that will help, guide, and support his friends (and indirectly his lesbian parents). The way in which he discloses and the times at which he chooses to disclose show that even 
though he shares easily and without shame or fear, he does not share the fact that his mother is gay spontaneously or without a good reason. His disclosures are, therefore, actions that are preceded by careful consideration of the circumstances.

When Tom discloses that he has lesbian parents to his friends, his purpose in doing so is to make his friends feel comfortable by resolving their uncertainty. When he observes indications of uncertainty, or discomfort, he takes these as cues to intervene and disclose. But he does not blurt out his disclosure in one set-piece speech. He gently questions his friend and waits for their response(s). He then deals in a kindly way with the reactions that follow and he also offers them support even to the extent of being willing to obtain the cooperation of his mother(s) in presenting this knowledge to the outside world, represented in this case by his friends' parents. Disclosure in such cases serves to ease levels of discomfort and to enhance mutual understanding, honesty, and openness. Tom is proud of the openness that exists among himself and his friends and he emphasizes this by saying that they keep no secrets from each other. Disclosure in such circumstances serves Tom's interests because it safeguards and maintains his friendships. Tom has realized that his friends might be averse to visiting him at home were they to feel uncomfortable in his domestic situation, and so his openness and having no secrets serves to secure his personal friendships.

To summarize this point, the children in this study are quick to recognize and understand the (sometimes quite subtle) signs that indicate that another person might not be $\mathrm{OK}$ with a disclosure of this kind. Apart from clearly indicative and relatively crude signs such as outright prejudice and discriminatory remarks,; e.g.:

Kim: ... He said to me: "Your mother is gay, and she is like this and does this-and-that and so on, you are going to become like your mother."

There is a whole body of more subtle and diffuse indicators that they are more likely to encounter among their friends that act as cues either to disclose or not disclose. Such indicators would include emotional discomfort, unfamiliarity, and uneasiness, or (in terms of body language) they might see their friends looking around with suspicion and observing transactions between their lesbian parents with a kind of withdrawn vigilance. Such behavior often constitutes a cue or sign for the children of lesbian-headed families in this study to intervene and to disclose because they need their 
friends to be as OK as possible with their lesbian-headed family. Disclosure then serves the purpose of establishing and legitimizing OKness and of enhancing the quality of openness between them and their friends (and between their friends and their lesbian parents). Most of the children are sensitive about how their friends might react, and they take care of their concerns or feelings after disclosing. For Tubbs and Moss (1994), disclosure represents an attempt to permit the values of authenticity to permeate our social relationships and, secondly, to enhance the intimacy, depth, and breadth of our relationships.

Disclosure serves to dispel feelings of awkwardness and uncertainty. It also serves to clarify existing situations in a way that enhances mutual understanding, honesty, and openness. They also know that disclosure will either prevent or minimize such uneasiness in their friends. Even though all these children know that disclosure is necessary if relationships are to develop and thrive, the actual process of deciding when to disclose and the possibility of foreseeing all possible reactions is more difficult to negotiate. Some of the children take great care to prepare their friends beforehand so that they will be at ease with their family's structure (as shown in Kashni's example). They want to disclose to their friends before their friends hear it from someone else, and they want to be in a position to handle any possible but unforeseen consequences themselves. Others disclose whenever an opportunity arises; for example, they will disclose if they notice a change in their friends' behavior (as can be seen with Tom). Sometimes a disclosure will happen spontaneously, as when a friend inadvertently asks a leading question. This, for example, happened to Danielle:

Oh yes, like, Alicia asked me, "Are they together? Do they sleep together?" Then I was, like, "Umm, yes. Where else would she sleep?" Alicia really caught me with that question. I just said, I'm sorry that I'm a liar. It's just that this stuff is very personal for me, and I can't share all my personal things. If I could tell her, and she could understand, then I would be very happy.

Because Danielle inevitably ended up in this situation where she was forced to confess, I regard this kind of situation as constituting a forced disclosure.

The way in which children of this study disclose also differs. Some disclose in a straightforward manner (as Kashni did) and invite questions or commentary (Tom). Others will wait until their friends ask them the leading question. Apart from Danielle's forced disclosure, Carl, for example, holds the following viewpoint: "If they want to know, they must ask me the 
questions-if they have any-and then I will answer them." Most of the time, disclosure is a one-off event that happens when a friend comes to visit them for the first time. As Carl explains: "We don't sit around and talk about it. It's just like something that happened a long time ago." But this explains why disclosure can be a continuous process: new people are crossing their paths all the time.

Disclosure may also happen differently in public and private spheres. Some of the children find disclosing to a more intimate circle of friends or one's immediate family is easier; for example, as Danielle states:

I don't actually share my secret. I only share that secret with my best friends.

Carl: I only tell people that I can trust. I'm certainly not going to shout about it from the rooftops. But I'll tell my friends.

For others, the more distant the person to whom they wish to disclose, and the less they know, the easier they find it to disclose:

Kim: But people in our closest circle, those people who matter to us, our friends and family - not all these people need to know because this is a personal matter. It's our own small world - and they must just accept it or lump it. I don't mind if people that I don't care about know or not.

Kim feels more comfortable with disclosing to a stranger than to people for whom she really cares, as people with whom she wants to form an intimate bond with may reject her if they get to know about her mothers' sexual orientation. These last two examples are also indicative of the level of OKness that is being displayed through their disclosure. Danielle frames her family structure as a secret, indicating that she might be less OK with having two mothers than, for example, Tom or Kashni.

Some of the children from lesbian-headed families reported that they were sometimes unsure of the other person's openness and wanted to get to know the other person better before disclosing. Such uncertainty serves the useful purpose of enabling them to see when nondisclosure might be a more appropriate strategy than disclosure in a particular situation. Kim, for example, stated that she prefers to choose those whom she will tell ("Not all of these people need to know") because sexual orientation is such a deeply personal (and frequently controversial) component of one's life. She is for me aware of her mother's position about her own sexuality. 
Danielle is also aware of this, as she says: "I was also scared that she would tell her mom. Then I thought, 'What will happen if her mom doesn't ever talk to my mom again?' That is scary." Their love for and loyalty to their mothers dictate that they will not disclose intimate information if they feel that it might harm their mothers or have a negative impact on their mothers' relationships. This insistence on the right to choose signifies that they are capable of moving toward a slightly more OK level as they themselves become more $\mathrm{OK}$ with having lesbian parents.

It is an incontrovertible assertion that negative and/or judgmental remarks motivated by conservative ideologies, ignorance, or even unadulterated spite and cruelty will reduce any person's willingness to be open and to disclose (Greene, 2000; Hudak \& Kihn, 2001). The children's awareness that different viewpoints do exist in society influences the viability of their disclosure processes. They will sometimes only disclose on the basis of what they intuit another person's opinions and attitudes to be. An awareness that people may judge and reject them caused some children to change significant details when they meet new people. For example, they might describe the co-mom as an aunt or friend of their mother:

Luanne: I am not going to say that my mother has a girlfriend. I just keep quiet. ... I would just tell them that she is my aunt because I never know whether they will reject me or not because of that, or perhaps become judgmental or unpleasant. It is not necessary for everyone to know these details. But if they ask me directly, I will tell them.

Danielle: I say she is a friend. I say she actually lives with my mom because they are best friends.

This phenomenon is quite frequently referred to in the literature (although most researchers refer back to Bozett's strategies of disclosure that were conceived in 1980). What happens is that either the children or the parents themselves will refer to the social mother as an aunt or a friend in order to discourage other people from asking probing or potentially controversial questions (Bozett, 1980; Johnson \& O'Connor, 2001; Paechter, 2000; Pennington, 1987; Ray \& Gregory, 2001; Vanfraussen, Ponjaert-Kristoffersen \& Brewaeys, 2002). I call this strategy masked disclosure. Masked disclosure means that children change significant details during disclosure either in order to protect themselves or their mothers against possible prejudice. This masked disclosure permits them to protect themselves and their 
parents or to protect and shield the other person, who might feel uncomfortable about the concept and reality of lesbian parents and it usually discourages (sensitive) people from asking any further probing questions.

There are also times when even though some of the children are not willing to disclose their family structure to just anyone, they are $\mathrm{OK}$ when someone finds out incidentally or by chance. This signals yet another higher level of being $\mathrm{OK}$ with the family structure and with disclosing, even though the occasion and means of such disclosures might be passive, indirect, and incidental:

Kashni: Which doesn't bother me. ... If they hear about my parents it's fine. They're usually fine with it as well.

Kim: Not everyone needs to know. And even if they do get to know, then it is, like, "So what's the big deal?"

Carl: After the photos had been taken, a few of us were standing around in a group. Then one of the guys (they were not exactly afraid, but you could see the apprehension in their eyes), asked me "Do you have two mothers, Carl? Or is the one lady your mother and the other lady your step-mother?" Something like that. I can't really remember their exact words. ... When they had recovered from that shock, they said, "But she's a woman!" And so I said, "So?" And after that, they never again asked me any other questions about my parents.

\section{Being OK Not to Disclose}

Children growing up in a lesbian-headed family are confronted with prejudices against their parent's sexuality and with hostile societal discourses that construct what and how a family ought to be. They are aware of the divergence between the dominant narrative in society and of what they personally experience at home. They are aware that one has to be intelligently selective about the people to whom one will disclose. They all know that not everyone is sympathetic to the concept of lesbian parents and that different people have different beliefs about what is moral and what is not. Paechter (2000) asserts that children are torn between a desire not to make a big deal of the situation and a realization that if one is going to tell people, one needs to do it selectively, carefully, and thoughtfully.

In addition, it seems as if these children are aware of the difference between denial and discretion. Most of them regard discretion as an effective strategy for protecting relationships and for respecting the opinions and 
values of others (although they might not agree with them). In an important sense, they are preserving the stability of the social and family order by appearing to pay homage to a set of societal values with which they might privately disagree. Let me explore this by using Luanne as an example:

Luanne: When we meet someone that we don't know and whose attitudes are unknown to us, we just say that Hannah is my aunt, so no one actually knows. ... We just don't want to advertise that my parents are gay. We all just want to get on with our everyday lives, and we hardly ever bring up questions like this when we are alone. ... Not everyone is open and OK with this kind of situation.

The silence that Luanne prefers to exercise outside the safety of her intimate circles, the fact that she does not deliberately disclose except if someone asks her directly, and the fact that they construct her co-mom as an aunt signifies that she is protecting herself, her mothers, and even the other people who are involved with her and their domestic situation. But why should she feel this need to protect? Her observation that "not everyone is open and OK" reveals that she is quite aware of prejudice and discrimination and has resolved to protect herself and those she cares for against the possibility of being ridiculed or worse. Another explanation might be that because different people have different moral standards, discretion acts an effective strategy to protect effective relationships and promote peace and harmony in her situation. In spite of these strategies, Luanne does not necessarily deny who or what her parents are. On the contrary, her effective use of what is a sensible strategy in a largely hostile or indifferent world means that she possesses an intelligent and well-informed understanding of her parents' sexual orientation and of how this might be disturbing to people in the outside world.

At times the children of lesbian parents experience such a strong sense of being OK that they cannot understand why having lesbian parents should bother anyone else. It is as though they refrain from accepting responsibility for anyone else's inability to feel that having lesbian parents and lesbian-headed families is an acceptable alternative to having the more usual opposite-gender parents. Some of the children assume that their friends know what their domestic situation entails and that any struggle that they might have in coming to terms with their family constellation is not their problem. 
Carl: If someone doesn't want to accept me because my parents are gay, then that's OK. I've got lots of friends. I don't need people like that. ... Most of my friends never even raise the question. If any of them have a problem with my mothers' orientation, then it is their problem. Not mine. ... But if they want to know, they must ask me the questions, if they have any, and then I will answer them.

Erid: If they want to know, I will tell them.... They have to find out if they want to know.

They also feel that the onus is on their friends to ask questions if they either do not know or suspect and feel uneasy and uncomfortable. Another child, Kim, however, took the position that having lesbian parents is an undeniable part of her family's reality ("It is our own small world.") that it is a given and nonnegotiable. These more outgoing children are also not bothered by the possibility that someone might find out because having lesbian parents is not an issue for them. They do not fear public opinion, and I surmise that they seldom even think about it. For them, their families are ordinary. Because their family structure is not an issue for them, they do not feel a need to disclose. They obviously also feel that if anyone else were to find out, the outcome for them and their families would not be disturbing or anxiety provoking. Exposure does not disturb their sense of being OK because, as far as they are concerned, "It's nothing" (Tom), it is ordinary.

In spite of this, there are times when even they are reluctant to disclose, and they become irritated if they are pushed to share the intimate details of their lives. In some cases, they do not like prying into their family constellation and try to prevent or cut short expository analyses or questions. They connect a sense of being OK on this level with an absence of talking or asking, and so they attempt to silence or cut short explanations, worries, concerns, or awkward questions.

Danielle: My friend said, "So you don't have a dad. Instead, you have like three mothers." And I answered: "Yes!" It's, like, hey, cool, but that's all I'm saying!

Erid: I don't always answer questions like that. But sometimes they do ask me, and I just say to them, "I don't feel like telling you now."

This is what I refer to as minimal disclosure. Sometimes the children will utilize this when they sense that the other person is merely curious and 
that they probably do not accept the OKness of lesbian-headed families. Another explanation might be that the child does not want the conversation to elaborate, maybe to the uneasiness that the topic entails for them or to protect the other person. The children in this study reported that they will then tell such inquirers as little as possible to answer their question and that they will not elaborate extensively or share more than is needed to answer the question. Sometimes they will also phrase their answer in such a direct (or even aggressive) manner that it discourages any further questions.

Most of the children growing up in lesbian-headed families have the ability to anticipate apprehension, anxiety, or uneasiness in others. This ability to read and interpret social cues leads them to respond proactively. The sensitivity they reveal in recognizing other people's behaviors and perceptions makes them aware of the possibility of teasing, mocking, and prejudice. The possibility of a negative outcome in a certain situation might cause them to opt for silence rather than disclosure as a preventative measure in awkward circumstances:

Kashni: Sometimes one just doesn't know. ... Some people are just uncomfortable with it, and, yes, that can sometimes create a difficult situation. ... I could just sense it. She always had excuses. There was always some or other reason why she couldn't come. Then I knew. You suddenly realize what is happening.

Most frequently, it is the perceived risk of arousing prejudice and discrimination, rather than the actual event itself, that makes them decide in favor of silence:

Danielle: I don't actually know what they're going to do. I just get a bad feeling that they're going to do something.

In addition, most of them at one time or another have been teased, mocked, and ridiculed about their parents' sexuality, and this makes them wary about the possibility of that it could happen again.

Danielle: They will tease me.... It is difficult. There are not many people that are like that. And it's just. ... They will do something to me, like kill me or something. Or they would say, "At least my parents are better than yours."

Erid: Most people act normally. Some are nice. Others are not. They are the bad ones... they tease you. 
Kim: But there was this one occasion that I want to tell you about. As I was walking past one of my brother's best friends, he said: "Look! She's a lesbian." I thought that they were talking about me, and, obviously, that was a topic about which I was most sensitive. I was so hurt that I started to cry.

Staying silent confers significant benefits. Remaining silent means that they are not exposed to the negative reactions of others, and this relieves them of the necessity of having to process their own or their friends' negative emotions or discomfort.

Erid: That is why they are my friends. They don't ask me questions.

O'Connell (1999) notes that "secrecy, remaining silent or lying" (p. 275 ) is perceived by many children of gay parents to be a vital strategy for maintaining relationships. I regard silence (not disclosing) as an effective strategy for dealing with stereotypical perceptions. As a matter of course, they also deliberately try to avoid other children who are likely to vent prejudice about lesbian parents. In other words, they have learned to be practical and proactive in the organization of their daily lives. These qualities significantly enhance their ability to live productive and rational lives. This may be another reason why some children are OK not to disclose: their experience has given them the ability and maturity to see that other people might not be ready to be confronted with this information:

Kashni: Sometimes one just doesn't know. ... Some people are just uncomfortable with it, and, yes, that can sometimes create a difficult situation.

\section{Nondisclosure and Not Being OK}

There are, however, instances where nondisclosure (Bozett, 1987) suggests to me that the child involved is not being OK because he or she has lesbian parents. Although this is especially evident in one boy's story (Ryland), this surfaced with some of the other children as well. Some of the children that I interviewed reported that they were afraid that someone would find out about their family structure. For them, the only way to manage, negotiate, and reconcile this divergence is by keeping quiet, hiding, and not disclosing: 
Danielle: I'm not going to tell anybody. ... It's a secret.

Ryland: That's why I have to keep it a secret, so that people don't tease me. ... If anyone finds out, I'll run away from school!

They construct their having two mothers as a secret that could shame them and their families if it were revealed. Previous experiences of being teased and mocked have sensitized them to the perception that they cannot simply disclose to people at random and without careful consideration because, in society as they know it, there are people who would reject and hurt them (or worse) should they learn the family secret. The secrecy and silence of these children are part of the effort they make to protect themselves:

Ryland: I haven't told anyone. Only my teacher [who is his father's fiancée] knows about my other mother. ... No one talks about it because no one knows about it. It's only my family that knows about it, and a few other close people. ... It's not wrong! There is nothing wrong with it. We don't tell the children at school, and that's how I want to keep it. Now if Danielle (for example) goes and tells everyone, "I've got two mothers at home," then we will have big problems to deal with.

The disadvantage of not disclosing when nondisclosure stems from fear is that they continue to live with the fear that someone might find out and that they continue to feel that they might be ostracized, isolated, or worse if their mothers' sexual orientation should become known (Pennington, 1987). Other authors are also of the opinion that children who are struggling to accept their mothers' sexual orientation will often (because of a fear that their mothers' sexual orientation might be discovered) become anxious, withdrawn, hypervigilant, and secretive (Clunis \& Green, 2000; John, 1994; O’Connell, 1999; Pennington, 1987).

For such children, forming new friendships becomes an anxiety provoking and fragile trade-off between trying to get to know someone and allowing them to get to know oneself while at the same time remaining scared of what might happen if the secret should slip out. Gerschon, Tschann, and Jemerin (1999) state that children of lesbian parents sometimes felt a need for secrecy and experience a sense of isolation because they are bearers of a secret that has been imposed upon them:

Ryland: I don't talk about it. If I say anything, I talk only about my mom and dad because it is none of their business! It's like, if other 
children ask questions, I just keep quiet, or I say “I don't want to talk about it."

This serves to separate and isolate them from their peers. These children frame their attempts to make friends against the hurt and humiliation they remember when previous attempts produced uncomfortable consequences and hurtful incidents and reactions:

Kim: I honestly didn't think that it would attract so much attention. But you know what young kids are like! There's nothing they love more than something sensational to gossip and snigger about. And I was, of course, still in primary school. But, yes, some of the children were saying things like, "You are going to become like your mother," and "This girl is a sinful child of Satan." But that's OK. I survived. ... But I couldn't go to my school friends and just pour my heart out to them because I would never know who they would tell.

Not being OK when others know about their parents' sexual orientation creates a need for privacy and silence, and such privacy can be maintained by nondisclosure.

To summarize, the OKness of children growing up in lesbian-headed families cannot be isolated from the interactions that they have with other people. There exists a strong linkage between OKness and disclosure (and nondisclosure). I conclude that these children negotiate their position with the outside world from these three different positions: (a) a sense of being OK when one discloses; (b) a sense of being OK not to disclose; and (c) complete nondisclosure and an accompanying sense of being not OK. I propose that children growing up in lesbian-headed families experience different levels of being OK and that, because of this, they express different levels of disclosure.

From the relationship between OKness and disclosure, the notion of the OKness and open-mindedness of others that children with lesbian parents engage with become apparent. I will now continue by examining the relationship between awareness of the OKness and perceived openmindedness of other people by children from lesbian-headed families and how the interaction they may or may not have influences their relationships. 


\section{OKness and Open-Mindedness of Others}

Even though I did not explore the experiences and reactions of the friends, peers, or other people that the children I interviewed came into contact with, the children reported that certain of their friends seemed more open-minded and more $\mathrm{OK}$ with the phenomenon of lesbian-headed families than did others:

Kashni: Some people say it's cool, it's just got to be cool—having two mothers as parents.

Some mentioned how other children (such as classmates) would talk about other people while assuming that they (the children) shared the same racist or conservative premises as the interlocutors. This kind of disjunction of sensibility is quite common among relative strangers in a society where a wide range of opinions exists among people who otherwise seem similar:

Kashni: Like, on this one particular day we were all standing at the bus stop, and a guy comes walking past with his arm around a girl. One could see that they were, like, together. Maybe even married or something like that. Then, some of the girls started making spiteful comments and noises. Why? Because the guy was Black and the girl was White. Then I remembered my previous school where we White girls dated Black guys and it didn't matter at all. ... So I stood there thinking to myself, "If race is such a big issue for you guys and you can't handle that, then how on earth will I be able to tell you that my parents are gay?" I looked at them ... and I thought to myself: "Do I really want to be friends with any of you?" So, I pick my friends very carefully, and I don't hang out with children who are like that. If I have to be with them, I just keep quiet, and I say nothing.

The indicators or markers that the children in the study used to establish conclusions about whether their classmates would more likely to be openminded and tolerant included the way in which their friends (but also other classmates) interacted with them, whether or not they asked questions of a pertinent kind, whether they were willing and happy to come for sleepovers or not, and how they reacted in the presence of their two mothers. (I hypothesize that these other children also experience degrees of OKness and open-mindedness that vary from time to time and place to place in their lives.) 
It seems that when a child in a lesbian-headed family is open about having two mothers and perceives that her friends are open-minded and tolerant of sexual diversity, disclosure might enhance the authenticity of the relationship. There is no doubt that the children in this study wanted to establish straightforward and honest relationships with their friends and other significant people. In propitious circumstances, disclosure enhances openness, while the ideal of openness enhances the quality of disclosure. In addition, openness is valued as an ideal by the children in this study because of their awareness and appreciation of the importance of open relationships:

Tom: When I invite my friends to my house, I want them to feel comfortable. So then, if they don't know about my two mothers, I tell them. It doesn't help if I keep secrets from them and then they have to wonder what is going on. But then they understand. I put them in the picture. My friends and I are all very straightforward with each other.

Kashni: But in the case of my best friends, those friends I talk to every day, then I must tell them . .. otherwise, I just feel uncomfortable. If they come to my home and they don't understand the situation before the time, then it could be very uncomfortable for them, especially if they have come for a sleepover.

The support that the children in this study offer their friends through their acts of disclosure augments and enriches the quality of openness in their friendships and relationships. Openness serves the purpose of facilitating and deepening feelings of reassurance, reliability, and trust among friends. This correlates with what Buhrmester and Prager (1995) have established: that self-disclosure addresses some very basic concerns of the discloser and serves the function of enhancing relationship development. The disclosure also signals OKness in the friendship and with the lesbian-headed families. The more OKness there is in a relationship, the more openness there is likely to be. OKness and openness enhance the quality of authentic relationships. Even if the family structure of having lesbian parents is never explicitly discussed, openness about other things is still possible in friendships where open-mindedness, tolerance, and OKness prevail as personal values: 
Researcher: What do your friends say when they come to sleep over? Kashni: Nothing. They're just fine with it. They just call my moms "Aunty Anriëtte" and "Aunty Zané." No, they're quite happy with it.

Tom and Researcher: But what about your other friends' parents? Do you know how they react or feel?

Kashni: Oh, I don't know. I suppose that they don't even talk about it or know anything about it. My friends wouldn't tell them because it's certainly not important to them. They know everything is all right. ... We know everything about each other.

A point may be reached where it might even become irrelevant to even talk about the parents' sexuality, especially among young people who are less conditioned by heteronormative ideologies and who are more influenced by the pervasive tolerance of dissimilar lifestyles that prevails in some alternative Western-influenced youth cultures. (One might note that some modern alternative youth cultures - although representative of a minority - are characterized by extreme intolerance of difference and diversity. This is a disturbing feature of contemporary Western culture.)

The position of being OK not to disclose, however, will probably result in a lesser degree of openness because the other person will have to come to conclusions on their own:

Carl: I suppose they must have had questions that they wanted to ask me. But they never asked! Except this one friend who asked a few questions. They obviously all know the setup by now, but they don't ask me.

In such situations, their adaptation to the family structure will depend partly on their own open-mindedness, OKness, and familiarity with alternative family configurations.

Interactions among children in lesbian-headed families and their classmates or friends were at times characterized by the friends or classmates asking questions for different reasons. The reasons included being unsure or mere curiosity and interest:

Carl: We were here one day, and Tiaan asked me whether my moms were still attending that church because they attended the same church for a while, and I said, "No, they are going to a gay church now." He 
looked at me in amazement and said, "To a gay church?" So I said, "Didn't you know that my moms were gay?" And he said, "Oh, don't talk nonsense!" And he kept on denying that it was possible until I went and got some family photographs to show him.... I was quite surprised by his reaction. But, in the end, he just said, "OK," and that was that.

But it was the process of asking questions that furthered openness among them. Openness in most cases thus engenders authentic relationships, and both of these are connected to OKness, awareness, support, and disclosure.

Thus far I have examined the relationship between awareness and disclosure, OKness, and disclosure and the perceived open-mindedness of other people by children from lesbian-headed families. I considered these interrelated concepts with specific reference to disclosure in exploring the ways in which children growing up in lesbian-headed families are aware of the dominant discourses and narratives in society and how this awareness influences their interaction with others. Finally, let me summarize this discussion by focusing on the interconnectedness between the key aspects that have emerged.

\section{Interconnectedness Between Awareness, OKness, Open-Mindedness, and Openness and Disclosure}

As I focused on the way in which children of this sample growing up in lesbian-headed families experienced their family in the context of a heteronormative society, the one aspect that received more attention and that emerged most strongly in my findings was their interaction with others, which, in their context, means, mainly, disclosure. This does not negate the importance and relevance of the other four aspects and their interconnectedness and their significance for children growing up in lesbian-headed families.

Children from lesbian-headed families that I interviewed disclosed when they become aware that their friends feel uneasy about their lesbian parents. Their disclosure serves as an intervention that helps their friends to feel more at ease and OK with the reality of their lesbian parents. Disclosure and OKness are directly linked because OKness increases the frequency and utility of disclosure. Being OK with having two mothers implies that one might be more willing to disclose that information. Conversely, being not OK will diminish the frequency of disclosure because it is obvious that a person is less likely or willing to disclose from a position of fear. 
Fears of this kind are grounded in memories of prejudice and other painful or embarrassing experiences that were precipitated by disclosure. Once children have successfully disclosed to friends or peers and the outcome of the disclosure has been favorable, their OKness is augmented. The satisfaction they feel once they have carried out successful disclosures probably also enhances OKness in their friends. This may be because the children of lesbian-headed families disclose as a result of having become aware of their friends' uneasiness, and they intervene to make their friends feel more OK. OKness once again leads to openness between friends and openness in other significant relationships in which the focus on the family structure of a lesbian-headed family might become less central in the awareness of everyone involved. Disclosure, in turn, seems to increase and empower OKness and openness in others. The children in this study were also aware that openness between them and others has a potential to enhance authentic and healthy relationships. When they realized that a prerequisite for authenticity between them and their friends was that they had to be more open in their relationships, they tended to be far more appreciative of the value of disclosure. This, in turn, encouraged them to be more supportive of their friends. Because they saw that these qualities contributed to mutual understanding, the children were aware of the benefits that accrued from being open and honest. This, in turn, facilitated the growth of healthy relationships.

\section{CONCLUSION}

Findings from a study exploring the experiences of children growing up in lesbian-headed families were discussed in this article. The study focused on eight children (four girls and four boys) from five families. The findings revealed that a common denominator among all eight children was that they were acutely aware of the propensity of people to react in diverse ways to the notion of lesbian-headed and the idea of such couples raising children. This awareness endowed them with unusual sensitivity that characterizes all their social interactions.

The children experienced varying levels of open-mindedness among their friends and other significant individuals with whom they interact in their daily lives. The children also exhibited differences in their degree of OKness with the experience of having lesbian parents. Disclosure, in turn, appears to affect a child's OKness: when a child from a lesbian-headed family senses uneasiness on the part of friends, he may choose to discuss 
the matter openly as a way of making them feel more OK. Their OKness, in turn, encourages openness within the friendship as well as in other significant relationships.

This study can only account for what it set out to answer. The limitations of this study are inherent to the decisions that were made when I designed this research. These decisions, however, also contributed to the strength of the study. Since this is qualitative research, I offered an understanding of children growing up in lesbian-headed families from their perspectives. The study is limited by what the children in this study reported about their lives and what they were able to convey in their own idiosyncratic language (the way in which they speak and are able to formulate their ideas).

All the children and all the parents involved in this study gave their consent to what they understood me to be doing, and all of them were willing to proceed with me on this journey. The exploration of experiences of children growing up in lesbian-headed families is thus limited to the experiences of those who were willing to participate. While the research was based on eight children's shared experiences, it has a wider relevance in the sense that by understanding and reflecting on their experiences, I was able to obtain some insight into how lesbian-headed families function and how they themselves negotiate the social construction of lesbian-headed families. Because this is a narrative inquiry, I was able to attain some depth with regard to the insights that I obtained into their experiences.

My preconceptions were, to a certain extent, fixed or given, and even though I have been open about them, this contingency might well be what makes me a social constructor. Even though I embarked on this journey with an open mind so that I could explore the stories in the field, my overall perception and views were informed by my working assumption that lesbian-headed families are different only because of the heteronormativity of society. Because the inquiry was inductive, it permitted me to be open to the discovery of new things that I did not or could not have anticipated in the beginning. This study did not set out to prove or elaborate on a certain theory, and it did not begin with a hypothesis that indicated what I was likely to find in the course of the research.

Since available research on children's experiences is limited in South Africa, I relied on similar and/or related research in other countries such as the United States, the U.K., Europe, and Australia (Clunis \& Green, 2000; Gershon et al., 1999; Johnson \& O'Connor 2001; O'Connell, 1999; Paechter, 2000; Patterson, 1992, 1997; Ray \& Gregory, 2001; Tasker \& Golombok, 1997). Even though this study did not aim to compare different cultural or environmental influences with one another, it seems that there 
is a universal trend emerging that children growing up in lesbian-headed households face more or less similar challenges of prejudice, stigmatization, and teasing. On the other hand, there is also evidence that these children also received support from friends and peers; they experienced open-mindedness, tolerance, and acceptance; and they displayed a sensitive awareness in their relationships with others. All of these factors in turn influenced the disclosure process.

Further research is warranted in terms of in-depth case studies as well as longitudinal and follow-up studies to explore how their experiences might change over time. Similar research needs to be done for children growing up in gay-headed (male couples) households in South Africa. Studies that explicate how parents and children integrate and make sense of their experiences might also be valuable. Such studies would focus on family dynamics and relationships between parents and children. Friendships that develop between children from different lesbian-headed families were an unanticipated and interesting phenomenon that emerged from this study. Further studies might illuminate this valuable asset. Research into the discourses on lesbian-headed families that appear in the media as well as how children growing up in lesbian-headed families construct concepts of normality are also essential.

The essence for me is that the children from lesbian-headed families from the research that I conducted in a changing South African context seem to be aware without exception of the perceptions and worldviews of people out there in the world. They seem to accept diverse perceptions, which range from some people being blunt and outspoken in their aversion to gays, to some who are more polite, tolerant, and circumspect, while others will be sufficiently open-minded and open-hearted and open to accept the diversity inherent in human nature. These children realize more clearly as they mature that many important, trustworthy, and admirable people are prepared to celebrate diversity and uniqueness. As this happens, their recognition of open-mindedness in others, their awareness, their own openness, and their willingness to disclose all work together to create a coherent and reliable ideology of growing up in lesbian-headed families.

\section{REFERENCES}

Alvesson, M., \& Sköldberg, R. (2000). Reflexive methodology: New vistas for qualitative research. Thousand Oaks, CA: Sage. 
Bozett, F. W. (1980). How and why gay fathers disclose their homosexuality to their children. Family Relations, 29, 173-179.

Bozett, F. W. (1987). Gay and lesbian parents. New York: Praeger.

Buhrmester, D., \& Prager, K. (1995). Patterns and functions of self-disclosure during childhood and adolescence. In K. J. Rotenberg (Ed.), Disclosure processes in children and adolescents (pp. 10-56). Cambridge: Cambridge University Press.

Clandinin, D. J., \& Connelly, F. M. (2000). Narrative inquiry, experiences, and story in the qualitative research. San Francisco: Jossey-Bass.

Clunis, D. M., \& Green, G. D. (2000). The lesbian parenting book (2nd ed.). New York: Seal Press.

Creswell, J. W. (2002). Educational research. Upper Saddle River, NJ: Merrill Prentice Hall.

Denzin, N. K., \& Lincoln, Y. S. (Eds.). (2000). The handbook of qualitative research (2nd ed.). Thousand Oaks, CA: Sage.

Dunne, G. A. (2000). Opting into motherhood: Lesbians blurring the boundaries and transforming the meaning of parenthood and kinship. Gender \& Society, 14(1), 11-35.

Gershon, T. D., Tschann, J. M., \& Jemerin, J. M. (1999). Stigmatization, self-esteem, and coping among the adolescent children of lesbian mothers. Journal of Adolescent Health, $24,437-445$.

Greene, B. (2000). Beyond heterosexism and across the cultural divide. In B. Greene \& G. L. Croom (Eds.), Education, research and practice in lesbian, gay, bisexual and transgender psychology (pp. 1-45). Thousand Oaks, CA: Sage.

Hudak, G. M., \& Kihn, P. (2001). Labelling: Pedagogy and politics. New York: Routledge Falmer Press.

Jenness, V., \& Richman, K. D. (2002). Anti-gay and lesbian violence and its discontents in lesbian \& gay psychology. In D. Richardson \& S. Seidman (Eds.), Handbook of lesbian and gay studies (pp. 403-414). Thousand Oaks, CA: Sage.

John, N. (1994). Pretended families: On being a gay parent. In M. Gevisser \& E. Cameron (Eds.), Defiant desire (pp. 342-347). Braamfontein: Ravan Press.

Johnson, S. M., \& O'Connor, E. (2001). For lesbian parents: Your guide to helping your family grow up happy, healthy, and proud. New York: Guilford.

Jordaan, D. W. (1998). Homoseksuele ouerskap: 'n grondwetlike analise. De jure ac legibus, 31(2), 302-321.

Kenyon, G. M., \& Randall, L. W. (1997). Restorying our lives: Personal growth through autobiographical reflection. Westport, CT: Praeger.

Kübler-Ross, E. (Ed.). (1986). Death: The final stage of growth. New York: Simon \& Schuster.

Lieblich, A., Tuval-Mashiach, R., \& Zilber, T. (1998). Narrative research. Thousand Oaks, CA: Sage.

Mason, J. (2002). Qualitative researching (2nd ed.). Thousand Oaks, CA: Sage.

Morse, J. M., \& Richards, L. (2002). Read me first for a user's guide to qualitative methods. Thousand Oaks, CA: Sage.

O'Connell, A. (1999). Voices from the heart: The developmental impact of a mother's lesbianism on her adolescent children. In J. Laird (Ed.), Lesbians and lesbian families (pp. 261-280). New York: Columbia Press. 
Paechter, C. (2000). Growing up with a lesbian mother: A theoretical based analysis of personal experience. Sexualities, 3(4), 395-408.

Patterson, C. J. (1992). Children of lesbian and gay parents. Child Development, 63, 10251042.

Patterson, C. J. (1997). Children of lesbian and gay parents. Advances in Clinical Child Psychology, 19, 235-282.

Patton, M. Q. (1990). Qualitative evaluation and research methods. Newbury Park, CA: Sage.

Pennington, S. B. (1987). Children of lesbian mothers. In F. W. Bozett (Ed.), Gay and lesbian parents (pp. 58-74). New York: Praeger.

Ray, V., \& Gregory, R. (2001). School experiences of the children of lesbian and gay parents. Family Matters, 59, 27-35.

Schwandt, T. A. (2000). Three epistemological stances for qualitative inquiry. In N. K. Denzin \& Y. Lincoln (Eds.), Handbook of qualitative research (2nd ed.; pp. 189-213). Thousand Oaks, CA: Sage.

Singh, D. (1995). Discrimination against lesbians in family law. South African Journal on Human Rights, 11(4), 571-581.

Tasker, F., \& Golombok, S. (1997). Growing up in a lesbian family: Effects on child development. New York: Guilford.

Tubbs, S. L., \& Moss, S. (1994). Human communication (7th ed.). New York: McGraw-Hill.

Underhill, G. (2003, June). The story of us. Femina, 72-75.

Vanfraussen, K., Ponjaert-Kristoffersen, I. \& Brewaeys, A. (2002). What does it mean for youngsters to grow up in a lesbian family created by means of donor insemination? Journal of Reproductive and Infant Psychology, 20(4), 237-252.

Willig, C. (2001). Introducing qualitative research in psychology: Adventures in theory and method. Buckingham: Open University Press. 